\title{
Parametric study of portable floating type biogas plant
}

\author{
Ravi P. Agrahari, ${ }^{1, *}$, G. N. Tiwari ${ }^{1}$ \\ ${ }^{1}$ Centre for Energy Studies, Indian Institute of Technology, Delhi, Hauz khas, New Delhi, India-110016 \\ * Corresponding author. Tel: +91 9911809 808, E-mail: ravipagrahari2010@yahoo.com, \\ ravipagrahari_iitd24@yahoo.com
}

\begin{abstract}
In this paper, an attempt has been made to design and test the performance of a portable floating type biogas plant of volume capacity $0.018 \mathrm{~m} 3$ for outdoor climatic condition of New Delhi, India. The field study has been carried under the monsoonal season of New Delhi, India. In this experiment, we have taken an aluminium made digester of $30 \mathrm{Kg}$ slurry capacity for batch system. In the batch system, the slurry has been added once to the digester for whole duration of the process. The rate of biogas production with slurry temperature has been observed.

It has been observed that (i) the biogas production depends strongly on slurry temperature and (ii) the retention period is nearly 85 days. The range of slurry and ambient temperature of atmosphere recorded during the observed period have been found as 26 to $42{ }^{\circ} \mathrm{C}$ and 30 to $40{ }^{\circ} \mathrm{C}$ respectively. Physical and chemical analysis of biogas and slurry have also been carried out. Further, the $\mathrm{CO} 2$ mitigation and carbon credit has also been evaluated for the present system.
\end{abstract}

Keywords: Biogas, Batch system, Carbon credit, Digester.

\section{Introduction}

Biogas technology provides an alternate source of energy in rural India, and is an appropriate technology that meets the basic need for cooking fuel in rural areas by using local resources, viz. cattle waste and other organic wastes. Realization of this potential and fact that India supports the largest cattle wealth led to the promotion of National Biogas Programme in major way in the late 1970s as an answer to the growing fuel crisis. In India alone, there are an estimated over 250 million cattle and if one third of the dung produced annually from these is available for production of biogas, more than 12 million biogas plants can be installed which have the estimated biogas potential capacity of 17,000 MW.

Biogas is produced from organic wastes by concerned action of various group of anaerobic bacteria through anaerobic decomposition. Anaerobic decomposition is a two-stage process as specific bacteria feed on certain organic materials. In the first stage, acidic bacteria dismantle the complex organic molecules into peptides, glycerol, alcohol and the simpler sugars. When these compounds have been produced in sufficient quantities, a second type of bacteria starts to convert these simpler compounds into methane. These methane producing bacteria are particularly influenced by the ambient conditions, which can slow or halt the process completely. Globally, the reduction of green house gas emissions particularly of $\mathrm{CO}_{2}$ has become more important. Currently much of the carbon dioxide emitted to the atmosphere is a result of anthropogenic activities from the use of the fossil fuel in the transportation and energy sectors. Significant emission reductions may be achieved in the energy sector by improving efficiency through the use of alternative fuels. Through the use of biogas plant we can save the $\mathrm{CO}_{2}$ emission in the atmosphere which has been measured in the term of carbon credit.

Carbon credit is a key component of national and international attempts to mitigate the growth in concentrations of green house gases (GHGs). One Carbon Credit is equal to one ton of carbon, which is the chief element of carbon dioxide. Carbon trading is an application of an emission trading approach through carbon credit. Greenhouse gas emissions are capped and 
then markets are used to allocate the emissions among the group of regulated sources. The idea is to allow market mechanisms to drive industrial and commercial processes in the direction of low emissions than are used when there is no cost to emitting carbon dioxide and other GHGs into the atmosphere. Since GHG mitigation projects generate credits, this approach can be used to finance carbon reduction schemes between trading partners and around the world.

Usmani et al (1996) have analysed the performance of a greenhouse integrated biogas plant. In this paper their basic aim was to reduce thermal loss to ambient in harsh cold climates. According to Lau et al. (1987) due to the lower temperature, biogas production decreases drastically and may stop. Thus, for enhancing biogas production, a higher digester temperature than ambient temperature is required. The green house concept should be integrated for larger capacity biogas plant. Tiwari et al. (1988) and Tiwari and Chandra (1986) have suggested that the rate of biogas production and the period to achieve the optimum temperature are function of the temperature of the slurry. Also, for a required production rate of biogas, the period to achieve the optimum temperature should be reduced. Tiwari et al. (1992) have suggested heating of the slurry by a heat exanger connected to a flat plate collector. Gupta et al. (1998), Sodha et al. (1987, 1989), Tiwari et al. (1997) have suggested installation of PVC greenhouse type structure over a biogas plant. This allowed solar heating of the substrate from $18{ }^{\circ} \mathrm{C}$ to about $37^{\circ} \mathrm{C}$. Kumar et al. (2008) have done experiments with solar greenhouse assisted biogas plant in hilly region and have come to conclusion that biogas- green house hybrid system may be successful in hilly regions where average temperature remains below $37{ }^{\circ} \mathrm{C}$ throughout the year. Prabhakant et al. (2009) evaluate the carbon credits earned by energy security in India and also analyses the return on capital for biogas plants with and without embodied energy.

The $70 \%$ of livestock in India is owned by $67 \%$ of small and marginal farmers and by the land less farmers. The $60 \%$ of livestock farming labor is provided by women and more than $90 \%$ of work related to care of animals is rendered by womenfolk of the family. India ranks fifth after Australia, China, Iran, and New Zealand. The fabrication of biogas plant is tried with different materials based on which the cost of installation is highly dependent. The few data of biogas production and its composition $\left(\mathrm{CH}_{4}\right.$ fraction) with the operating temperature of slurry is available in the literature. In this paper an attempt has been made to study the biogas production with its composition with the temperature throughout retention period w.e.f. July 12, 2010 to September 29, 2010.

\section{Experimental setup and instrumentation}

An aluminium made biogas chamber of $30 \mathrm{~kg}$ slurry capacity has been used under the outdoor simulation above the ground, so that the digester and dome both can direct receive the solar radiation. The diameter and height of digester have been taken as 0.34 and $0.38 \mathrm{~m}$ respectively. Similarly the diameter, depth and weight of dome have been taken as $0.30 \mathrm{~m}$, $0.35 \mathrm{~m}$ and $0.18 \mathrm{~kg}$, respectively.

Aluminium metal is more efficient to increase the sufficient temperature inside the digester which increases the production rate of biogas. Four calibrated thermocouples have been used to measure ambient, slurry, gas and dome temperature by using digital temperature indicator of resolution $0.1{ }^{\circ} \mathrm{C}$. A thermocouple is a junction between two different metals that produces a voltage related to temperature difference. Thermocouples are a widely used type of temperature sensor for measurement and control and can also be used to convert heat into electric power. They are inexpensive and interchangeable, are supplied fitted with standard connectors, and can measure a wide range of temperatures. The main limitation is accuracy 
system errors of less than one degree Celsius can be difficult to achieve. These thermocouples are calibrated by constant temperature controlled calibration baths. A calibration bath is a uniform temperature enclosure with a constant temperature setting that can be adjusted manually or with automation. This field study has been done at the Solar Energy Park, IIT Delhi, New Delhi, under the monsoonal season, which is highly under the fluctuating environmental condition.

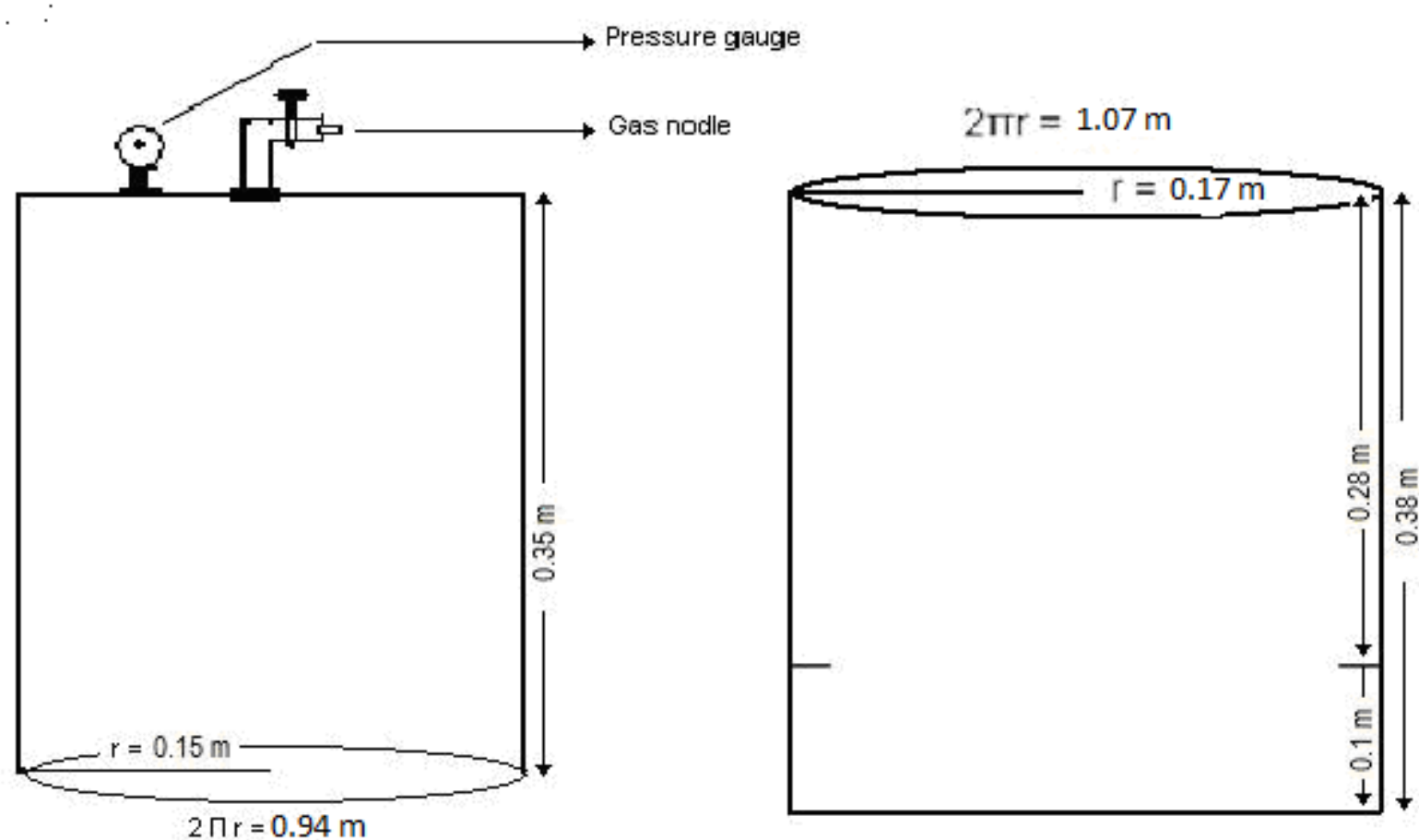

(a)

Figure 1. Schematic view (a) Dome (b) Digester

(b)

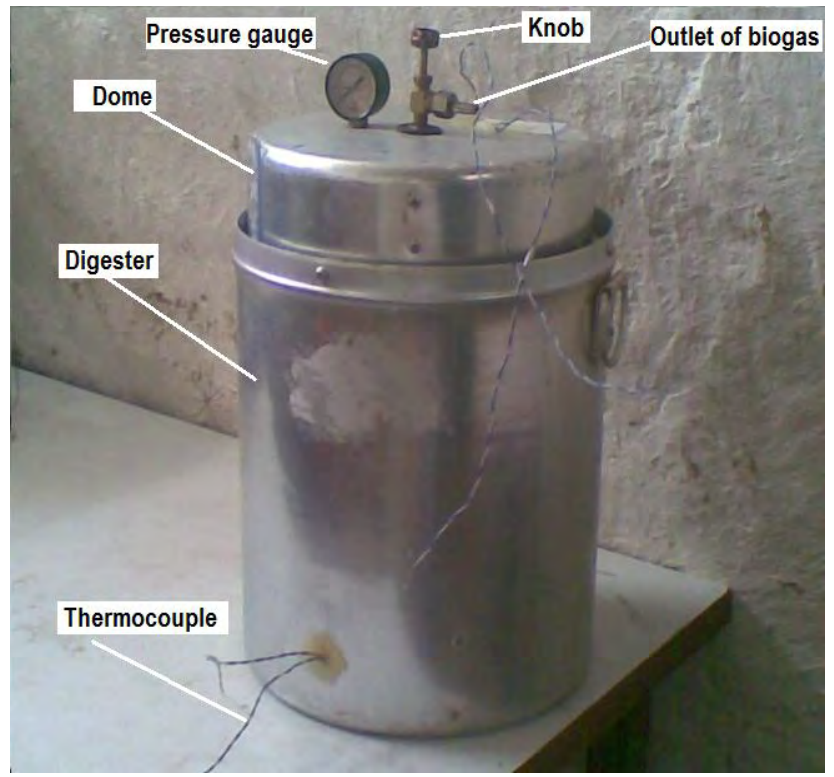

Figure 2. : Photograph of experimental setup
These observation has been taken during day time due to presence of sunlight at 9:00 am, 1:00 pm and 5:00 pm during the month of July to September 2010 (monsoon season) in Delhi, India. Ambient temperature, relative humidity, average precipitation and solar intensity have been measured during this experiment. Gas production have been recorded on daily basis by the observation of upliftment of dome and volume production. This biogas sample have been taken out by the help of toddler bags, which is safe to carry biogas without any leakage and entry of atmospheric air, which has been tested through gas chromatography. 


\section{Methodology and experimental observations}

Different parameters like solar intensity, ambient temperature, slurry temperature, average humidity and average precipitation are measured on daily basis. These data have been taken at the interval of 4:00 hours between 9:00 am to 5:00 pm due to presence of solar radiation. Three readings have been taken in every day at 9:00 am, 1:00 pm and 5:00 pm. Under the analysis we have calculated the average of solar intensity and relative humidity at these three different times in a day upto every two weeks, until the biogas production inside the biogas chamber stop. In this manner we have also calculated the average ambient temperature and average slurry temperature to find the different result and observation, which shown in figure 3 and figure 4 . We have also tried to measure the pressure inside the dome through the help of pressure gauge in $\mathrm{kg} / \mathrm{cm}^{2}$ but it did not provide any data due to generation of very less pressure inside the dome. The production rate and methane fraction has also been observed under the influence of various temperature range during the monsoonal season in New Delhi, India.

\section{Results and discussions}

In this study, it has been observed that the production of biogas is dependent upon the temperature and the solar intensity of the atmosphere. The methane fraction has found to increase up to first six weeks and then it become constant. The synthesis of biogas have been started from the third day of the slurry feeding inside the biogas chamber. There has no role of humidity and precipitation under biogas production. Initially solar intensity increased upto two weeks but after this it decreases due to cloudy weather condition, because the monsoonal season is very fluctuating. Where as the slurry temperature was always more than ambient temperature during the whole experimentation period. These all parameters are shown in figure 3. In this continuation, initially in first two week, the rate of biogas production was very fast but after it gradually decreases. During experimentation, the minimum and maximum fraction range of methane and the rate of biogas production has also been observed in every week which shown in figure 4.

The total biogas volume produced during the experimentation has been recorded $0.378 \mathrm{~m}^{3}$ under three month of observation. So the total volume of biogas produced in a year $(4 \times 0.378$

$\mathrm{m}^{3}$ ) $1.512 \mathrm{~m}^{3}$. Therefore the total carbon credits which has been earned in a year 0.019 units/year or $€ 0.285$ / year. Carbon dioxide mitigation and carbon credit are calculated below:

\section{Carbon credit earned by biogas plant}

Total volume of biogas produced during experiment (July to September) $=0.378 \mathrm{~m}^{3}$

Total volume of biogas produced in a year $=4 \times 0.378 \mathrm{~m}^{3}=1.512 \mathrm{~m}^{3}$

(Taking calorific value of biogas $=6 \mathrm{kWh} / \mathrm{m}^{3}$ )

So total energy produced in a year $=6 \times 1.512=9.072 \mathrm{kWh}$

(Taking $1 \mathrm{kWh}=2 \mathrm{~kg} \mathrm{CO} 2$ under mitigation)

Total $\mathrm{CO}_{2}$ mitigated $=9.072 \times 2=18.144 \mathrm{~kg} /$ year

It is known that in one meter cube of biogas there is an average $62.5 \%$ natural gas by volume and the weight of natural gas is $0.68 \mathrm{~kg} / \mathrm{m}^{3}$ 
The weight of natural gas present in the given volume of biogas $=0.68 \times 1.512=1.028 \mathrm{~kg} /$ year

Methane is 18.25 times more potent than carbon dioxide. Taking this ratio the equivalent carbon dioxide can be computed as $=18.25 \times 1.028=18.761 \mathrm{~kg} /$ year $=0.019$ ton $/$ year ( 1 ton $\mathrm{CO}_{2}=1$ credit)

Therefore total carbon credits earned in a year $=0.019$ units $/$ year $=€ 0.285 /$ year.

(Assuming 1 carbon credit $=€ 15 /$ unit)

Table 1. Different parameters (solar intensity, relative humidity, ambient temperature, slurry temperature and average precipitation) and their effect with biogas production and methane fraction.

\begin{tabular}{|c|c|c|c|c|c|c|c|}
\hline \multirow{4}{*}{$\begin{array}{l}\text { Avg. solar } \\
\text { intensity } \\
(\mathrm{W} / \mathrm{m} 2)\end{array}$} & Observation & 2 week & 4 week & 6 week & 8 week & 10 week & 12 week \\
\hline & 9:00 am & 230 & 248 & 226.5 & 215 & 218 & 209.5 \\
\hline & $1: 00 \mathrm{pm}$ & 491.5 & 504 & 613 & 511 & 474.5 & 557.5 \\
\hline & $5: 00 \mathrm{pm}$ & 121.5 & 124.5 & 145 & 134.5 & 131.5 & 166.5 \\
\hline $\begin{array}{l}\text { (AVG.) } \\
\text { (W/m2) }\end{array}$ & $\begin{array}{l}\text { (9:00 am to } \\
\text { 5:00 pm) }\end{array}$ & 281 & 292.2 & 328.2 & 286.8 & 274.7 & 311.2 \\
\hline \multirow{3}{*}{$\begin{array}{l}\text { Avg. humidity } \\
\text { (\%) }\end{array}$} & 9:00 am & 67.1 & 73 & 76.5 & 80.2 & 64.2 & 64.9 \\
\hline & $1: 00 \mathrm{pm}$ & 52.6 & 63 & 69.9 & 67.3 & 56.9 & 60.3 \\
\hline & $5: 00 \mathrm{pm}$ & 61.6 & 70 & 79.3 & 80.3 & 58.9 & 67.7 \\
\hline $\begin{array}{c}\text { (AVG.) } \\
(\%)\end{array}$ & $\begin{array}{c}\text { (9:00 am to } \\
\text { 5:00 pm) }\end{array}$ & 60.4 & 68.7 & 75.2 & 75.9 & 60.0 & 64.3 \\
\hline $\begin{array}{c}\text { Avg. Ambient } \\
\text { temperature } \\
\left({ }^{\circ} \mathrm{C}\right)\end{array}$ & $\begin{array}{l}\text { Whole day } \\
\text { (24 hours) }\end{array}$ & 31 & 30.5 & 30.3 & 30.0 & 29.5 & 29 \\
\hline $\begin{array}{c}\text { Avg. Slurry } \\
\text { temperature } \\
\left({ }^{\circ} \mathrm{C}\right)\end{array}$ & $\begin{array}{l}\text { (9:00 am to } \\
\text { 5:00 pm) }\end{array}$ & 32.4 & 32.5 & 35.1 & 36.5 & 35.7 & 35.1 \\
\hline $\begin{array}{l}\text { Volume of biogas } \\
\text { (m3) }\end{array}$ & $\begin{array}{l}\text { Whole day } \\
\text { (24 hours) }\end{array}$ & 0.033 & 0.133 & 0.102 & 0.040 & 0.054 & 0.016 \\
\hline $\begin{array}{c}\text { Methane } \\
\text { fraction(min.) } \\
(\%)\end{array}$ & $\begin{array}{l}\text { Whole day } \\
\text { (24 hours) }\end{array}$ & 5 & 35 & 40 & 40 & 40 & 30 \\
\hline $\begin{array}{c}\text { Methane } \\
\text { fraction(max.) } \\
(\%)\end{array}$ & $\begin{array}{l}\text { Whole day } \\
\text { ( } 24 \text { hours) }\end{array}$ & 40 & 55 & 55 & 55 & 55 & 40 \\
\hline
\end{tabular}




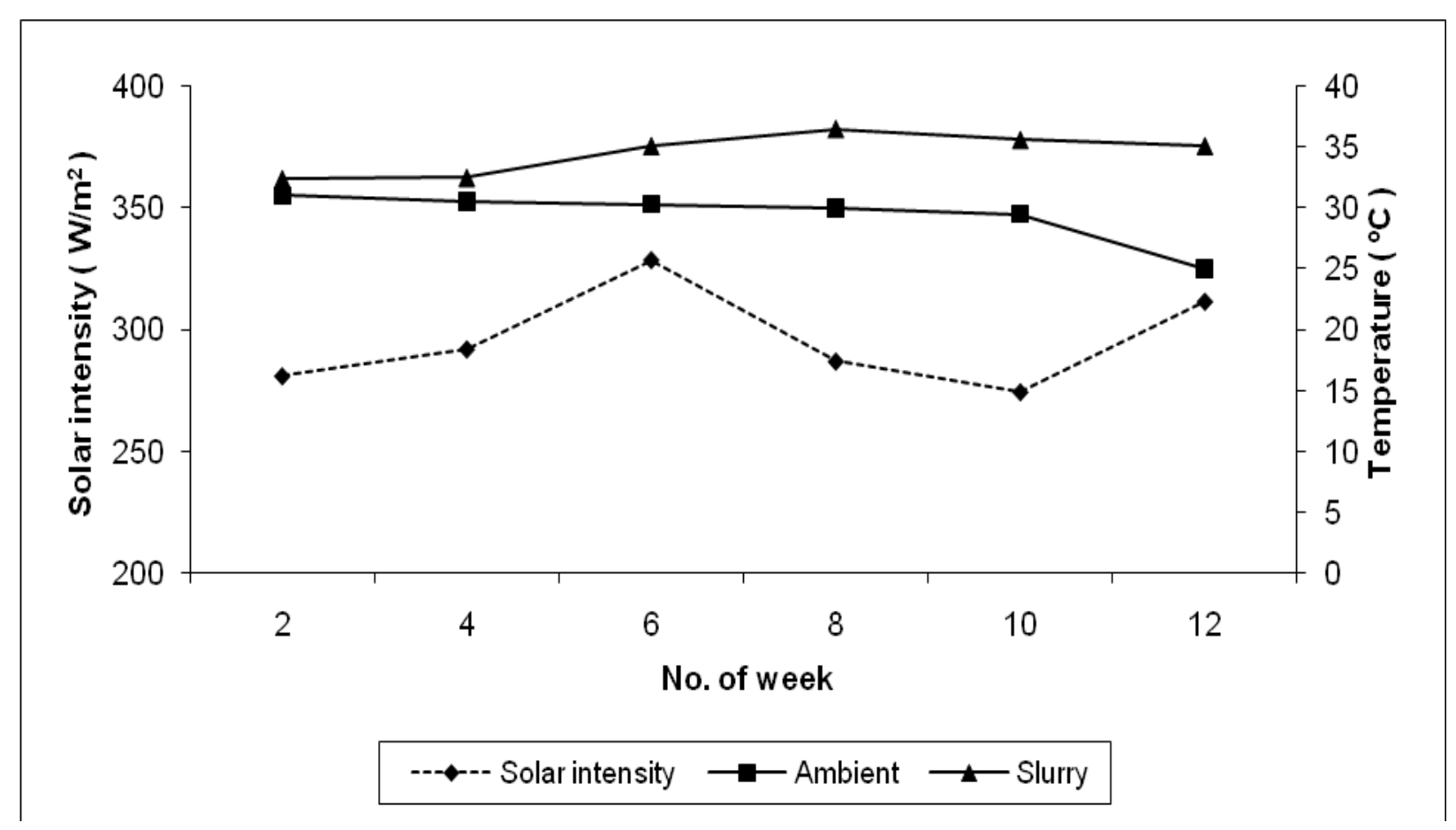

Figure 3. The weekly variation of solar intensity, ambient temperature and slurry temperature

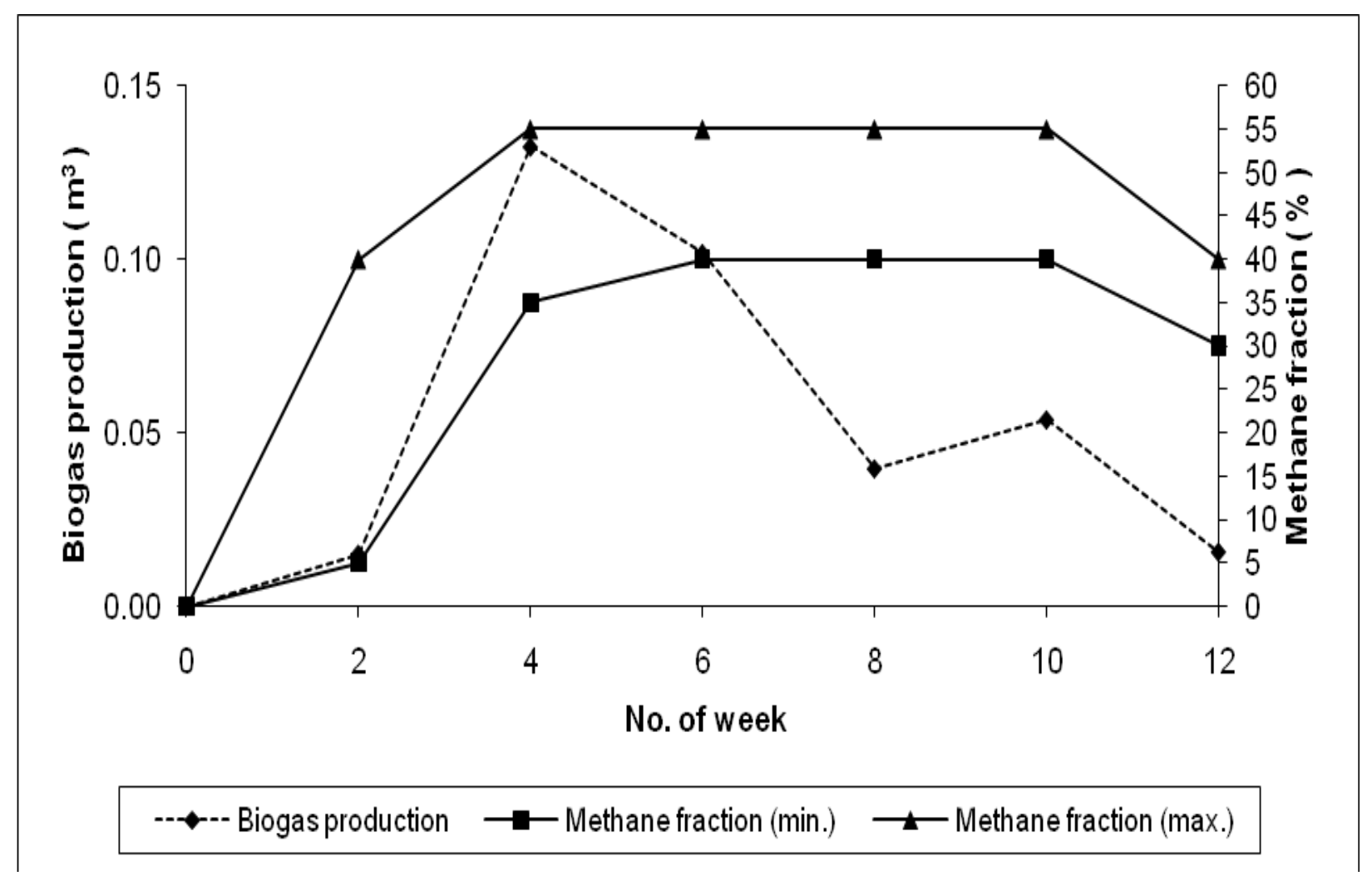

Figure 4. Rate of biogas production and methane fraction shown on weekly basis 


\section{Conclusions and recommendations}

In this experiment it has been observed that the biogas plant is successful during the monsoon season because here the temperature varies between 26 to $39^{\circ} \mathrm{C}$. Aluminium made biogas plant is other alternative which we can use for biogas production because it is more durable, less prone to corrosion, light in weight and more heat absorbing capacity comparative to iron made biogas plant, so it maintains sufficient temperature inside the digester which increases the rate of production of biogas. These are also economically feasible for developing country specially for India. We can also increase the slurry temperature inside the digester if we coat a black paint on the surface of aluminium made biogas chamber. Because it will increase the absorbtion capacity of sunlight on its surface. In next experiment we will also analyse the rate of production of biogas and its methane fraction under greenhouse chamber.

\section{Acknowledgement}

We are thankful to the Centre for Rural Development and Technology (CRDT), IIT Delhi, for their help to measure the biogas fraction and analysis of spent sample.

\section{References}

[1] Usmani J.A., Tiwari G.N. and Chandra A., 1996. Performance Characteristic of greenhouse integrated biogas system. Energy Conservation and Management. 37(9): 1423-1433

[2] Lau A.K., Staley L.M., 1987. A design procedure for an air-type solar heating system for green houses. Energy in Agriculture. 6(2): 95-119

[3] Tiwari G.N., Sharma S.B. and Gupta S.P., 1988. Transient performance of a horizontal floating gas holder type biogas plant. Energy Conservation and Management. 28(3): 235239

[4] Tiwari G.N., Chandra A., 1986. Solar assisted biogas system: a new approach. Energy Conversion and Management. 26(2): 147-150

[5] Tiwari G.N., Singh S.K. and Thakur K., 1992. Design criteria for an active biogas plant. Energy. 17(10): 955-958

[6] Gupta R.A., Rai S.N. and Tiwari G.N., 1988. An improved solar assisted biogas plant (fixed dome type): a transient analysis. Energy Conservation and Management. 28(1): 5357

[7] Sodha M.S., Ram S., Bansal N.K. and Bansal P.K., 1987. Effect of PVC greenhouse in increasing the biogas production in temperature cold climate conditions. Energy Conversion and Management. 27(1): 83-90

[8] Sodha M.S., Goyal I. C., Kishor J., Jayashankar B.C. and Dayal M., 1989. Solar assisted biogas plants IV A: Experimental validation of a numerical model for slurry temperature in a glazed fixed-dome biogas plant. International Journal Energy Research. 13: 621-625

[9] Tiwari G.N., Dubey A.K. and Goyal R.K., 1997. Analytical study of an active winter greenhouse. Energy.; 22(4): 389-392

[10]Kumar K. Vinoth, Bai R. Kasturi, 2008. Solar greenhouse assisted biogas plant in hilly region - A field study. Solar Energy. 82: 911-917

[11] Prabhakant and G.N.Tiwari, 2009. Evolution of carbon credits earned by energy security in India. International Journal of Low Carbon Technologies. Vol 4: 42-51 